\title{
Physicochemical composition and fatty acids profile of the meat of lambs fed with cassava wastewater
}

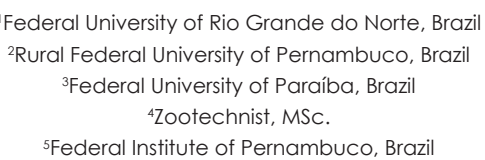

Stela Antas Urbano', Marcelo Andrade Ferreira², Paulo Sérgio de Azevedo ${ }^{3}$

Gustavo Araújo Vasconcelos ${ }^{4}$, Hilson Barreto Santos Filho ${ }^{5}$, Daniel Barros Cardoso 2

\begin{abstract}
The effects of replacing corn with cassava wastewater at 0; 25; $50 ; 75$ and $100 \%$ in the sheep diet over chemical composition, fatty acid profile and physical-chemical parameters of meat were studied. Forty Santa Inês breed sheep were slaughtered after 70 days of confinement. The moisture content of meat increased, while the crude protein and ether extract decreased linearly with the replacement. There was a quadratic effect for shear force with minimum force estimated at $2.78 \mathrm{~kg} / \mathrm{cm}^{2}$ with $54.25 \%$ replacement. There was a quadratic effect for C15:0 and C:17, 10.37 and 1.30 when the replacement was $46.25 \%$ and $68.50 \%$, respectively), increasing linearly for the $\mathrm{C} 18: 0$ and decreasing for the C22:0. For monounsaturated fatty acids there was a decreasing linear effect for $\mathrm{C} 14: 1$ and $\mathrm{C} 20: 1 \mathrm{n} 9$, and increasing to $\mathrm{C} 18: 1 \mathrm{n} 11$. For $\mathrm{C} 15: 1$ a quadratic effect was observed ( 1.48 when $26.75 \%$ of corn was replaced). As to the polyunsaturated fatty acids, there was a quadratic effect for $\mathrm{C} 18: 29 \mathrm{c} 11+$ ( 0.60 when replacement was $36.66 \%$ ). There was a linear decrease for relations polyunsaturated: saturated and $\omega 6: \omega 3$, without effect on other relations. Cassava wastewater alters the shear force and chemical and lipid composition of meat.
\end{abstract}

Keywords: alternative food, energy, shear force, cassava, lipid profile

\section{Introduction}

It is a fact that, in Brazil, sheep meat is yet consumed in small quantities when compared to poultry, bovine and swine meats. Data from Anvalpec (2011) highlight that the annual consumption per capita of sheep meat in the country lies around $0,7 \mathrm{~kg}$, while $39 \mathrm{~kg}$ of bovine, $44,5 \mathrm{~kg}$ of chicken and $13 \mathrm{~kg}$ of swine meats are consumed. Although the flock effectiveness partially explains part of this reduced consumption, it is known that the increase of the per capita consumption of sheep meat depends, doubtless, on the increase in the quality of the product made available for the consumer.

The modern consumer demands a qualitatively standardized sheep meat, without fat excess and with elevated softness. In this manner, the knowledge of the quality parameters - such as chemical composition, color, water holding capacity, losses during cooking and softness is indispensable to adequately produce and process the meat, aiming to obtain high quality and to proportionate a higher competitiveness among the other sources of animal origin.

Given the approach "meat x health", the fatty acids profile has a prominent role, being largely responsible for the meat labeling as "harmful to health". The fat of the adipose deposits of ruminant animals is rich in triglycerides, with the predominance of saturated fatty acids 
and a low amount of polyunsaturated fatty acids, not framing in the recommended profile by the human nutritionists, who suggest an increment in the consumption of polyunsaturated fatty acids, especially those of the $\omega-6$ and $\omega-3$ classes. Thus, given the diet influence over the lipid composition of the meat (Wood et al., 2008), the researchers of animal science aim, through dietary manipulation, to reduce the relation saturated/polyunsaturated, to equilibrate the relation $\omega-6 / \omega-3$ and to increase the levels of conjugated linoleic acid (CLA) in the lipid fraction of ruminant meat.

Considering the feeding importance over the effect on production and in the general characteristics of sheep meat, it justifies the necessity of studies on the influence of feeding over meat quality in sheep, aiming to detect alternative feeding systems which are adaptable to the breeding conditions of the Brazilian northeast (Madruga et al., 2005).

It was aimed to evaluate the effect of the replacement of corn for cassava wastewater in the diet of Santa Inês sheep over chemical composition, fatty acids profile and physical- chemical parameters (color, losses by cooking, shear force and water holding capacity) of the meat.

\section{Material and Methods}

The meat samples analyzed in this study were originated from 40 non-emasculated sheep of the Santa Inês breed, kept in confinement for 70 days and utilized in development essay performed in the Zootechny Department of the Federal Rural University of Pernambuco (UFRPE), located in Recife - PE.

The experimental diets were isoproteic, being the standard diet formulated to answer the demands for maintaining the animals with $24 \mathrm{~kg}$ and allowing average weight gain of $200 \mathrm{~g} \mathrm{day}^{-1}$. The chemical composition of the utilized ingredients is presented in Table 1. The diets consisted in levels of corn replacement for cassava wastewater in 0; 25; 50; 75 and $100 \%$ (Table 2). The utilized cassava wastewater, originated from the flour houses located in Glória do Goitá - PE, passed through a period of, at least, five days of rest so that it could be provided to the animals.

Table 1. Chemical composition of the utilized ingredients ( $g / \mathrm{kg} M S$ )

\begin{tabular}{|c|c|c|c|c|c|c|c|}
\hline Ingredient & $\mathrm{DM}^{1}$ & MM & OM & $\mathrm{CP}$ & $\mathrm{EE}$ & FDNcp & NFC \\
\hline Tifton hay & 864.9 & 59.2 & 940.8 & 73.5 & 15.1 & 718.3 & 133.9 \\
\hline Cassava wastewater & 67.2 & 24.7 & 975.3 & 10.3 & 3.0 & 1.7 & 960.3 \\
\hline Corn & 911.3 & 14.3 & 985.7 & 85.6 & 42.3 & 135.2 & 722.6 \\
\hline Soybean flour & 930.9 & 67.1 & 932.9 & 478.0 & 19.3 & 133.6 & 302.0 \\
\hline Wheat flour & 921.6 & 49.9 & 950.1 & 166.3 & 38.5 & 371.4 & 373.9 \\
\hline Urea & 990.0 & 2.0 & 998.0 & $2,800.0$ & - & - & - \\
\hline
\end{tabular}

Elapsed 70 experimental days, plus the adaptation period, the animals were subjected to hydric diet and solids fasting for 16 hours. At the slaughter moment, the animals were numbed through brain concussion, followed by exsanguinations through section of the carotid artery and jugular vein.

At the end of the skinning and evisceration, the head (sectioned at the atlanto-occipital joint) and the feet (sectioned at the metacarpal and metatarsal joints) were removed and the hot carcass weight (HCW) was registered. The obtained carcasses were cooled for 24 hours at $\pm 4^{\circ} \mathrm{C}$ in refrigerating chamber, hanged by the common calcaneal tendon through hooks, with the metatarsal joints distanced in $14 \mathrm{~cm}$. After 24 hours of refrigeration, the carcasses were longitudinally sectioned and the half-carcasses were weighed, being the left carcasses divided into six anatomic regions, according to the methodology described by Cezar \& Sousa (2007), originating the commercial meat cuts, namely: neck, shoulder, leg, loin and hindquarter. The loins and left legs of each animal were identified, packed in vacuum in high density polyethylene bags and frozen at -18 ${ }^{\circ} \mathrm{C}$ to later performing of the laboratory tests.

The determinations of the losses by cooking and shear force were performed on the left loins (Longissimus lumborum) of each animal, 
according to methodology described by Wheeler et al. (1995). The losses by cooking were obtained by weight difference of the samples before and after cooking, and expressed in percentage.
The shear force was measured with the WarnerBratzler Shear Force (G-R MANUFACTURING CO., Model 3000) equipment, with load cell of $25 \mathrm{kgf}$, operating in a speed of $20 \mathrm{~cm} / \mathrm{min}$.

Table 2. Percentage and bromatological composition of the experimental diets

\begin{tabular}{|c|c|c|c|c|c|}
\hline \multirow{2}{*}{ Ingredients ( $\mathrm{g} / \mathrm{kg})$} & \multicolumn{5}{|c|}{ Replacement levels (\%) } \\
\hline & 0 & 25 & 50 & 75 & 100 \\
\hline Tifton hay & 500,00 & 500,00 & 500,00 & 500,00 & 500,00 \\
\hline Cassava wastewater & 0,00 & 58,50 & 116,70 & 174,90 & 233,10 \\
\hline Corn & 240,00 & 180,00 & 120,00 & 60,00 & 0,00 \\
\hline Soybean flour & 147,00 & 147,00 & 147,00 & 147,00 & 147,00 \\
\hline Wheat flour & 100,00 & 100,00 & 100,00 & 100,00 & 100,00 \\
\hline Urea & 0,00 & 1,50 & 3,30 & 5,10 & 6,90 \\
\hline Common salt & 3,00 & 3,00 & 3,00 & 3,00 & 3,00 \\
\hline Mineral salt & 10,00 & 10,00 & 10,00 & 10,00 & 10,00 \\
\hline \multicolumn{6}{|c|}{ Bromatological composition } \\
\hline $\mathrm{DM}^{1}$ & 892,1 & 518,9 & 366,4 & 283,2 & 230,8 \\
\hline$O M^{2}$ & 939,2 & 938,7 & 938,1 & 937,5 & 936,9 \\
\hline$C P^{2}$ & 144,2 & 143,8 & 144,4 & 144,9 & 145,4 \\
\hline $\mathrm{EE}^{2}$ & 24,4 & 22,0 & 19,7 & 17,3 & 14,9 \\
\hline$M^{2}$ & 60,8 & 61,3 & 61,9 & 62,5 & 63,1 \\
\hline FDNcp ${ }^{2}$ & 448,4 & 440,3 & 432,3 & 424,3 & 416,3 \\
\hline $\mathrm{FAD}^{2}$ & 240,1 & 237,7 & 235,3 & 232,9 & 230,5 \\
\hline $\mathrm{CHOT}^{2}$ & 770,6 & 772,9 & 774,0 & 775,3 & 776,6 \\
\hline $\mathrm{NFC}^{2}$ & 322,2 & 335,3 & 347,6 & 360,2 & 372,7 \\
\hline TDN ${ }^{2 *}$ & 654,6 & 645,0 & 602,8 & 652,1 & 588,9 \\
\hline
\end{tabular}

The color of the Longissimus lumborum muscle was measure after standardization of the cuts in a minimal thickness of $15 \mathrm{~mm}$, followed by air exposure for 30 minutes in refrigerated environment $\left( \pm 4^{\circ} \mathrm{C}\right)$, according to methodology described by Ramos \& Gomide (2009). The reading were performed with the aid of a colorimeter (KONICA MINOLTA, model CR-400), operating in the CIELAB system $\left(L^{*}, a^{*}, b^{*}\right)$, being $L^{*}$ the luminosity, variable from black $(0 \%)$ to white (100\%); $a^{*}$ the red color intensity, variable from green (-a) to yellow (+a); and b* the yellow color intensity, variable from blue (-b) to yellow (+b). Three measures were performed in different spots of the muscle, utilizing the average values for color representation.

The water holding capacity (WHC \%) was determined according to methodology described by Santos-Silva et al. (2002) and calculated through the following formula: WHC $(\%)=(P 2-P 1) / S \times 100$, in which "S" represents the sample weight; "P1" represents the initial weight of the filter paper; and "P2" the final weight of the filter paper.
The chemicalcomposition was performed from an aliquot of the Semimembranosus muscle, which was crushed and homogenized in blender and freeze-dried for later determinations of humidity, crude protein, ether extract and ash, according to methodology described by Silva \& Queiroz (2002).

The fat extraction for determination of the fatty acids profile in the Semimembranosus muscle was performed according to methodology by Folch et al. (1957) and the methylation according to the methodology described by Hartman \& Lago (1973). The identification and quantification of the fatty acids ethers were performed in gas chromatograph (VARIAN 430-GC, California, USA), coupled with flame ionization detector (FID), fused silica capillary column (CP WAX 52 CB, VARIAN) with dimensions of $60 \mathrm{~m} \times 0,25 \mathrm{~mm}$ and $0,25 \mu \mathrm{m}$ of film thickness. Helium was utilized as drag gas (flow rate of $1 \mathrm{~mL}$ ) $\mathrm{min}$ ). The initial temperature of the oven was 100 ${ }^{\circ} \mathrm{C}$, programmed to reach $240^{\circ} \mathrm{C}$, increasing 2,5 ${ }^{\circ} \mathrm{C}$ per minute, lasting for 20 minutes. The injector and detector temperatures were kept in $250^{\circ} \mathrm{C}$ 
and $260{ }^{\circ} \mathrm{C}$, respectively. The chromatograms were registered in the Galaxie Chromatography Data System software type. The fatty acids were identified through retention times comparison of the methyl esters of the samples with standards Supelco ME19-Kit (Fatty Acid Methyl Esters C6C22). The fatty acid results were quantified through area normalization of the methyl esters and expressed in area percentage.

The variable analysis were conducted adopting a completely random design, xccording with the model $Y_{i j}=\mu+T_{i}+\beta\left(X_{i j}-X\right)+e_{i j}$ in which $Y i j=$ observed value of the dependent variable; $\mu=$ general average; $\mathrm{Ti}=$ treatment effect $\mathrm{i}(\mathrm{i}=1$ to 5$) ; \beta(\mathrm{Xij}-\mathrm{X})=\mathrm{co}$-variable effect (initial body weight); eij = experimental error. The data were tabulated and later subjected to statistical analysis, utilizing the PROC MIXED proceeding of the statistical package SAS (Statistical Analysis System, version 9.1).

\section{Results and Discussion}

The replacement of corn for cassava wastewater caused a crescent linear effect in the meat humidity content and a decreasing effect in the contents of crude protein and ether extract, not being verified influence of the replacement over ash content (Table 3).

Table 3. Chemical composition of the meat in Santa Inês breed sheep fed with cassava wastewater in replacement to corn.

\begin{tabular}{|c|c|c|c|c|c|c|c|c|c|}
\hline \multirow{2}{*}{ Item (g/100g) } & \multicolumn{5}{|c|}{ Replacement levels (\%) } & \multirow{2}{*}{$C \vee(\%)$} & \multirow{2}{*}{$\begin{array}{l}\text { Regression } \\
\text { equation }\end{array}$} & \multirow{2}{*}{$r^{2}$} & \multirow{2}{*}{$P$} \\
\hline & 0 & 25 & 50 & 75 & 100 & & & & \\
\hline Humidity & 75,56 & 75,65 & 75,70 & 76,06 & 76,86 & 1,04 & 1 & 0,79 & $* *$ \\
\hline Ash & 1,46 & 1,63 & 1,35 & 1,33 & 1,38 & 19,34 & $\hat{Y}=1,43$ & - & $>0,05$ \\
\hline $\mathrm{CP}$ & 20,36 & 20,35 & 20,31 & 19,73 & 19,68 & 3,56 & 2 & 0,80 & * \\
\hline EE & 2,30 & 2,24 & 1,96 & 2,13 & 1,46 & 25,75 & 3 & 0,70 & $* *$ \\
\hline
\end{tabular}

(3) $\hat{Y}=2,3356-0,0071 \mathrm{M}: \mathrm{M}=\%$ of cassava wastewater in replacement to corn.

Bonagurio et al. (2004) cited that, generally, the increase in the fatty content decrease the humidity and protein contents, while the ash content suffer little variation. Considering that the inverse is also valid, the increase in the humidity content would be explainable by the reduction verified for the meat ether extract; however, according with the authors premise, it was expectable that the protein content linearly increased, a not verified fact in this study. Furthermore, Bressan et al. (2001) cited that meat humidity is inversely proportional to the weight at slaughter, what could also explain the increase in the humidity content of the meat given the lowest performances and weights at slaughter verified by Santos Filho et al. (2015) for animals which consumed higher levels of cassava wastewater in replacement to corn, in a work associated to the current research.

As to the chemical composition of the meat, Jardim et al. (2007) affirm that the reduction in the protein content relates to the slowdown of muscle growth, occurring a lower increase in protein. Although this slowdown normally occurs when maturity is reached, it is possible that, in this study, it might have been consequence of the lower protein ingestion. Santos Filho et al. (2015) verified an expressive reduction in the protein consumption in the animals which consumed cassava wastewater in replacement to corn, especially when the replacement was superior to $50 \%$, what might have led to a lower tissue deposition of the protein and, consequently, to a reduction in the protein content of the meat.

The meat ether extract corresponds to the lipids deposited within the cells and in their interior (Costa et al., 2012), being a good indicative of the intramuscular fat percentage of the carcass. Thus, the low values obtained are coherent with the characteristics of the animals of the Santa Inês breed, which normally do not produce carcasses with elevated fat contents, being reported in the literature values in the order of $2,5 \%$ for the lipid content of the meat of animals belonging to this genetic group (Costa et al., 2012). However, the linear decrease caused by the replacement reaffirms the nutrition importance over the chemical composition of sheep meat (Bonagurio et al., 2004), being probably explained by the reduction in the nutrient consumption, especially of energy, reported by Santos Filho et al. (2015), when they reaffirmed the nutrient consumption 
of these experimental animals. Costa et al. (2012) also verified a decrease in the lipid content of the meat in Santa Inês breed sheep when the consumption of metabolizable energy by the animals decreased.

Table 4. Physical parameters of the meat in Santa Inês breed sheep fed with cassava wastewater in replacement to corn

\begin{tabular}{|c|c|c|c|c|c|c|c|c|c|}
\hline \multirow{2}{*}{ Item } & \multicolumn{5}{|c|}{ Replacement levels (\%) } & \multirow{2}{*}{ CV (\%) } & \multirow{2}{*}{$\begin{array}{l}\text { Regression } \\
\text { equation }\end{array}$} & \multirow{2}{*}{$r^{2}$} & \multirow{2}{*}{$P$} \\
\hline & 0 & 25 & 50 & 75 & 100 & & & & \\
\hline WRC (\%) & 26,55 & 32,78 & 28,97 & 28,92 & 29,14 & 21,64 & $\hat{Y}=29,27$ & - & $>0,05$ \\
\hline LBC (\%) & 27,47 & 23,05 & 26,89 & 25,82 & 28,48 & 22,10 & $\hat{Y}=26,34$ & - & $>0,05$ \\
\hline $\mathrm{SF}\left(\mathrm{kg} / \mathrm{cm}^{2}\right)$ & 3,45 & 3,02 & 2,98 & 3,17 & 3,69 & 16,91 & 1 & 0,88 & $* *$ \\
\hline$L^{*}$ & 42,27 & 42,54 & 44,59 & 44,50 & 43,98 & 6,16 & $\hat{Y}=43,57$ & - & $>0,05$ \\
\hline$a^{*}$ & 15,96 & 15,90 & 16,75 & 16,05 & 15,65 & 10,54 & $\hat{Y}=16,06$ & - & $>0,05$ \\
\hline$b^{*}$ & 7,87 & 7,94 & 8,28 & 8,32 & 7,97 & 11,08 & $\hat{Y}=8,08$ & - & $>0,05$ \\
\hline
\end{tabular}

Concerning the physical parameters of meat, only the shear force was influenced by the replacement, for which a quadratic effect was verified, with minimal shear force estimated in $2,78 \mathrm{~kg} / \mathrm{cm}^{2}$ when the cassava wastewater replaced corn in 54,25\% (Table 4).

High fat levels protect cell integrity during the cooling and freezing, and decrease the water losses during cooking, being possible to infer that these variables are positively correlated. In this study, despite the reduction verified for the fat contents and the addition in humidity - which tends to increase the water losses - there was no variation for the losses by cooking. For sheep of the Santa Inês breed, Costa et al. (2012) cited losses in the order of $28,4 \%$, whilst Vieira et al. (2010) reported $23,5 \%$, in average, for weight losses caused by cooking, so that the values obtained in this essay are inside the interval reported in the consulted literature. It is important to highlight that the losses during cooking constitute an important quality measure, once that they are associated to meat yield in the act of consumption (Silva et al. 2008).

There was no effect of the replacement over the water retention capacity (WRC) parameter, which translates the meat capacity in retain water in the presence of external forces and which, in the moment of chewing, refers to a higher or lower succulence (Osório et al., 2009). Satisfactory WRC values imply in adequate values of losses by cooking, once that beefs with little capacity in retaining water present a quick juice outlet during cooking (Osório et al., 2009), with possible losses in the order of $50 \%$. Thus, according to the results obtained for the losses by cooking, it might be inferred that the verified values for WRC might be considered satisfactory, characterizing the meat as little exudative.

The main factor related to meat softness, instrumentally measured through maximum shear force, is the age of the animal; for being directly proportional to the state of collagen reticulation and to its number of crossed links, such as muscular fibers (Osório et al., 2009). Considering the homogeneity of the experimental animals as to the age, no variation in shear force was expected. However, in spite of the quadratic effect, the verified values allow to classify the meat as soft, since that all were inferior to $5 \mathrm{~kg} /$ $\mathrm{cm}^{2}$, limit advocated by Bianchini et al. (2007).

As to the meat color, despite the linear increase in the humidity content, no effect was verified over $L^{*}$, which tends to be higher as the highest is the water content in the meat. The value of $b^{*}$, which is influenced by the fat color due to the presence of beta-carotene (Pinheiro et al., 2009), also did not vary, although the fat content has considerably decreased. The absence of effect over the values of $L^{*}, a^{*}$ e b*, which indicate the meat color, corroborates with Osório et al. (2009), Who affirmed that in the ruminants the food type little influences in the meat color, due to the transformation that the nutrients undergo in the rumen.

In the analysis of the lipid fraction of the meat, 27 different fatty acids were identified, from which 12 are saturated (Table 5), nine are monounsaturated (Table 6) and six are polyunsaturated (Table 7). Within the indentified 
fatty acids, the palmitic (C16:0), stearic (C18:0) and oleic (C18:1) acids corresponded to approximately $80 \%$ of the total, reaffirming the prevalence of these acids in the lipid profile of the sheep meat, as cited by Madruga et al. (2005), Costa et al. (2009) and Arruda et al.
(2012), when they evaluated the sheep meat of the Santa Inês breed. Despite the variations occurred in the concentrations of some fatty acids, there was no effect of the replacement over the total of saturated, mono-unsaturated and poly-unsaturated fatty acids.

Table 5. Profile of saturated fatty acids (\% area) in the Semimembranosus muscle of Santa Inês sheep breed fed with cassava wastewater in replacement to corn.

\begin{tabular}{|c|c|c|c|c|c|c|c|c|c|}
\hline \multirow{2}{*}{$\begin{array}{l}\text { Saturated } \\
\text { fatty acids }\end{array}$} & \multicolumn{5}{|c|}{ Replacement levels (\%) } & \multirow{2}{*}{ CV(\%) } & \multirow{2}{*}{$\begin{array}{c}\text { Regression } \\
\text { equation }\end{array}$} & \multirow{2}{*}{$r^{2}$} & \multirow{2}{*}{$P$} \\
\hline & 0 & 25 & 50 & 75 & 100 & & & & \\
\hline C10:0 & 0,09 & 0,11 & 0,10 & 0,10 & 0,18 & 94,05 & $\hat{Y}=0,12$ & - & $>0,05$ \\
\hline $\mathrm{C} 12: 0$ & 0,12 & 0,12 & 0,07 & 0,09 & 0,16 & 93,23 & $\hat{Y}=0,11$ & - & $>0,05$ \\
\hline C 14:0 & 1,90 & 2,02 & 1,68 & 1,85 & 1,66 & 17,76 & $\hat{Y}=1,82$ & - & $>0,05$ \\
\hline C15:0 & 0,31 & 0,32 & 0,35 & 0,37 & 0,21 & 29,46 & 1 & 0,74 & $*$ \\
\hline $\mathrm{C} 16: 0$ & 22,38 & 23,08 & 21,75 & 23,13 & 21,67 & 5,02 & $\hat{Y}=22,40$ & - & $>0,05$ \\
\hline C17:0 & 0,90 & 0,95 & 1,15 & 1,26 & 0,76 & 30,81 & 2 & 0,63 & $*$ \\
\hline C18:0 & 15,41 & 15,04 & 15,87 & 16,15 & 16,82 & 7,92 & 3 & 0,82 & $*$ \\
\hline C19:0 & 0,21 & 0,21 & 0,27 & 0,19 & 0,23 & 48,21 & $\hat{Y}=0,22$ & - & $>0,05$ \\
\hline C20:0 & 0,39 & 0,34 & 0,40 & 0,38 & 0,39 & 37,45 & $\hat{Y}=0,38$ & - & $>0,05$ \\
\hline C22:0 & 0,14 & 0,02 & 0,02 & 0,02 & 0,00 & 184,12 & 4 & 0,63 & $*$ \\
\hline C23:0 & 2,33 & 1,81 & 2,65 & 2,17 & 3,27 & 30,94 & $\hat{Y}=2,45$ & - & $>0,05$ \\
\hline C24:0 & 0,26 & 0,25 & 0,23 & 0,19 & 0,19 & 76,96 & $\hat{Y}=0,23$ & - & $>0,05$ \\
\hline Total SFA & 44,48 & 44,30 & 44,56 & 45,94 & 45,55 & 3,61 & $\hat{Y}=44,97$ & - & $>0,05$ \\
\hline
\end{tabular}

Table 6. Profile of mono-unsaturated fatty acids (\% area) in the Semimembranosus muscle of Santa Inês breed sheep fed with cassava wastewater in replacement to corn

\begin{tabular}{|c|c|c|c|c|c|c|c|c|c|}
\hline \multirow{2}{*}{$\begin{array}{c}\text { Monounsaturated fatty } \\
\text { acids }\end{array}$} & \multicolumn{5}{|c|}{ Replacement levels (\%) } & \multirow{2}{*}{$C V(\%)$} & \multirow{2}{*}{$\begin{array}{l}\text { Regression } \\
\text { equation }\end{array}$} & \multirow{2}{*}{$r^{2}$} & \multirow{2}{*}{$P$} \\
\hline & 0 & 25 & 50 & 75 & 100 & & & & \\
\hline C14:1 & 0,08 & 0,08 & 0,04 & 0,06 & 0,00 & 39,43 & 1 & 0,65 & $* * *$ \\
\hline C15:1 & 1,57 & 1,52 & 1,67 & 1,46 & 2,31 & 15,42 & 2 & 0,72 & $* *$ \\
\hline C16:1 & 1,85 & 1,80 & 1,89 & 1,89 & 1,83 & 13,13 & $\hat{Y}=1,85$ & - & $>0,05$ \\
\hline C17:1 & 0,64 & 0,66 & 0,81 & 0,83 & 0,54 & 33,14 & $\hat{Y}=0,70$ & - & $>0,05$ \\
\hline C18:1 n9 cis & 42,69 & 43,51 & 42,31 & 42,49 & 40,80 & 3,94 & $\hat{Y}=42,36$ & - & $>0,05$ \\
\hline C18:1 n9 trans & 0,18 & 0,12 & 0,13 & 0,12 & 0,89 & 175,22 & $\hat{Y}=0,29$ & - & $>0,05$ \\
\hline C18:1 n1 1 & 1,90 & 1,85 & 1,97 & 1,78 & 3,43 & 44,36 & 3 & 0,46 & $*$ \\
\hline C20:1 n9 & 0,18 & 0,10 & 0,11 & 0,11 & 0,06 & 43,40 & 4 & 0,67 & $* *$ \\
\hline C22:1 n9 & 0,00 & 0,54 & 0,00 & 0,00 & 0,00 & 500,00 & $\hat{Y}=0,11$ & - & $>0,05$ \\
\hline Total MFA & 49,09 & 50,17 & 48,92 & 48,73 & 49,87 & 4,55 & $\hat{Y}=49,36$ & - & $>0,05$ \\
\hline
\end{tabular}

$0,0107 \mathrm{M}+1,6273 ;(3) \hat{Y}=1,5848+0,012 \mathrm{M} ;$ (4) $\hat{Y}=0,16-0,0009 \mathrm{M} ; \mathrm{M}=\%$ of cassava wastewater in replacement to corn.

Table 7. Profile of poly-unsaturated fatty acids (\% area) in the Semimembranosus muscle of Santa Inês breed sheep fed with cassava wastewater in replacement to corn.

\begin{tabular}{|c|c|c|c|c|c|c|c|c|c|}
\hline \multirow{2}{*}{$\begin{array}{l}\text { Poly-unsaturated fatty } \\
\text { acids }\end{array}$} & \multicolumn{5}{|c|}{ Replacement levels (\%) } & \multirow{2}{*}{$C \vee(\%)$} & \multirow{2}{*}{$\begin{array}{l}\text { Regression } \\
\text { equation }\end{array}$} & \multirow{2}{*}{$r^{2}$} & \multirow{2}{*}{$P$} \\
\hline & 0 & 25 & 50 & 75 & 100 & & & & \\
\hline C18:2 n6 cis & 4,15 & 4,44 & 4,92 & 3,95 & 2,74 & 36,84 & $\hat{Y}=4,04$ & - & $>0,05$ \\
\hline C18:2 n6 trans & 0,88 & 0,15 & 0,12 & 0,21 & 0,71 & 214,85 & $\hat{Y}=0,41$ & - & $>0,05$ \\
\hline C18:3 n3 & 0,16 & 0,14 & 0,38 & 0,30 & 0,46 & 123,65 & $\hat{Y}=0,29$ & - & $>0,05$ \\
\hline C18:29c $11 \dagger$ & 0,39 & 0,36 & 0,51 & 0,32 & 0,19 & 26,09 & 1 & 0,74 & $* *$ \\
\hline C20:4 n3 & 0,47 & 0,11 & 0,12 & 0,11 & 0,07 & 191,67 & $\hat{Y}=0,18$ & - & $>0,05$ \\
\hline C22:6 n3 & 0,38 & 0,34 & 0,47 & 0,43 & 0,40 & 57,23 & $\hat{Y}=0,40$ & - & $>0,05$ \\
\hline Total PFA & 6,43 & 5,53 & 6,50 & 5,32 & 4,58 & 26,36 & $\hat{Y}=5,67$ & - & $>0,05$ \\
\hline
\end{tabular}

A quadratic effect was verified for the C15:0 (maximum estimated value of 0,37 when the replacement was $46,25 \%$ ) and C17:0 (maximum estimated value of 1,30 when the replacement was 68,50\%), increasing linear effect for the $\mathrm{C} 18: 0$ and decreasing for the C22:0. Although it 
presents no Double links in its molecular structure, the C18:0 does not present hypercholesteromic effect (Bentes et al., 2009), being referenced as a desirable fatty acid, so that the increase in the concentration of this fatty acid does not turn the meat less healthy. The total of saturated fatty acids was similar to the values verified by Arruda et al. (2012), but inferior to those reported by Costa et al. (2009) and Madruga et al. (2005). It is worth adding that the human consumption of saturated fatty acids in a content superior to $15 \%$ of the daily dietetic energy is related to the increase in the blood levels of cholesterol and decrease in the activity of the LDL-cholesterol receptors, leading to situations of coronary heart diseases (Rioux \& Legrand, 2007).

For the monounsaturated fatty acids a linear decrease for the C14:1 and C20:1 n9 was verified and linear increase for the C18:1 $\mathrm{n} 11$. For the C15:1 a quadratic effect was observed, with maximum estimated value of 1,48 , when of the replacement of $26,75 \%$ of corn for cassava wastewater. The total of monounsaturated fatty acids was superior to the sum saturated fatty acids, and to the sums of monounsaturated fatty acids reported by Costa et al. (2009) for sheep of the same breed. According to Sposito et al. (2007), when monounsaturated fatty acids replace the saturated fatty acids in the diet, the cholesterol levels might be reduced. Thus, although the variations have been little expressive, the results point the nutritional quality of the lipid fraction of the meat in these animals.

Concerning poly-unsaturated fatty acids, quadratic effect was verified for the C18:2 9c 11 t, with maximum estimated value of 0,60 when the replacement was of $36,66 \%$. The poly-unsaturated fatty acids composed the lipid profile of the meat in small proportions, what is justified by the

Table 8. Averages of the relations within saturated, monounsaturated and poly-unsaturated fatty acids in the meat of Santa Inês breed sheep fed with cassava wastewater in replacement to corn.

\begin{tabular}{|c|c|c|c|c|c|c|c|c|c|}
\hline \multirow{2}{*}{ Relations } & \multicolumn{5}{|c|}{ Replacement levels (\%) } & \multirow{2}{*}{$\mathrm{CV}(\%)$} & \multirow{2}{*}{$\begin{array}{l}\text { Regression } \\
\text { equation }\end{array}$} & \multirow{2}{*}{$r^{2}$} & \multirow{2}{*}{$P$} \\
\hline & 0 & 25 & 50 & 75 & 100 & & & & \\
\hline MFA : SFA & 1,10 & 1,14 & 1,10 & 1,06 & 1,10 & 7,80 & $\hat{Y}=1,10$ & - & $>0,05$ \\
\hline PFA : SFA & 0,14 & 0,12 & 0,15 & 0,12 & 0,10 & 25,53 & 1 & 0,64 & $*$ \\
\hline DFA & 70,93 & 70,94 & 71,29 & 70,21 & 71,28 & 2,47 & $\hat{Y}=70,89$ & - & $>0,05$ \\
\hline$\omega 6: \omega 3$ & 6,21 & 9,10 & 5,86 & 5,07 & 2,13 & 50,98 & 2 & 0,59 & $* *$ \\
\hline $\mathrm{h}: \mathrm{H}$ & 1,97 & 1,92 & 2,02 & 1,88 & 1,90 & 7,86 & $\hat{Y}=1,94$ & - & $>0,05$ \\
\hline$(\mathrm{C} 18: 0+\mathrm{C} 18: 1) / \mathrm{C} 16: 0$ & 2,70 & 2,63 & 2,78 & 2,63 & 2,86 & 7,66 & $\hat{Y}=2,72$ & - & $>0,05$ \\
\hline
\end{tabular}


The low values verified for the relation AGP : AGS are characteristic of the ruminant meat and corroborate with the results of Arruda et al. (2012), however, the values were inferior to the 0,45 considered appropriate for human consumption nutrients, according with the British Department of Health and Social Care (Fernandes et al., 2009), aiming to avoid diseases related to the consumption of saturated fats. Scollan et al. (2005) cited that the normal value of the relation AGP : AGS in the meat of ruminants varies from 0,06 to 0,15 and affirm that, generally, dietetic manipulation does not turn this relation superior to these values due to ruminal biohydrogenation of the poly-unsaturated fatty acids.

As to the relation $\omega 6: \omega 3$, despite the decrease, is found to be nearer of the values 4:1 - 6:1 recommended by Herdmann et al. (2010). It is worth noting that the fatty acids of the series $\omega 3$ - precursors of the eicosapentaenoic (EPA) and the docosahexaenoic acids (DHA) - and $\omega 6$ precursors of the prostaglandins and leukotriens are involved in the prevention of cardiovascular diseases and hypertension (Urbano et al., 2014), being the consumption of these compounds highly recommended by nutritionists. Furthermore, the equilibrium maintaining between the $\omega 6$ and $\omega 3$ acids has a great importance, once that for the synthesis of its derivates, the $\omega 3$ and $\omega 6$ utilize the same enzymes, being the preference order of the substrates by the enzymes: omega-3 > omega-6 > omega-9 (Lima Júnior et al., 2011).

The relation $(\mathrm{C} 18: 0+\mathrm{C} 18: 1) / \mathrm{C} 16: 0$, which describes the beneficial effects of the different lipid types must, according to Maia et al. (2012), present values between 2 and 3 in sheep meat. In this study no influence of the replacement over this relation was verified, which presented an average value of 2,72 , fitting, therefore, in the values referenced in the literature.

The desirable fatty acids and the relation between hypocholesterolemic and hypercholesterolemic fatty acids did not vary according with the different levels of cassava wastewater in replacement to corn, and are in agreement with the values cited by Costa et al. (2009) and Arruda et al. (2012) for sheep of the same breed.

\section{Conclusions}

The replacement of corn for cassava wastewater in the diet of Santa Inês breed sheep has influence over the shear force and over the chemical and lipid compositions of the meat. However, the variations due to the replacement did not compromise the general quality of the meat, measured by the physicalchemical parameters, suggesting that the recommendation of the replacement level must be oriented by other parameters, such as cost, availability and animal development.

\section{References}

ANUALPEC. 2011 . Anuário Estatístico da Pecuária de Corte. São Paulo: FNP Consultoria \& Comércio.

Arruda, P.C.L., Pereira, E.S., Pimentel, P.G., Bomfim, M.A.D., Mizubuti, I.Y., Ribeiro, E.L.A., Fontenele, R.M., Regadas Filho, J.G.L. 2012. Perfil de ácidos graxos no Longissimus dorsi de cordeiros Santa Inês alimentados com diferentes níveis energéticos. Semina: Ciencias Agrárias, 33:1229-1240.

Bentes, A.S., Souza, H.A.L., Mendonça, X.M.F.D., Simões, M.G. 2009. Caracterização física e química e perfil lipídico de três espécies de peixes amazônicos. Revista Brasileira de Tecnologia Agroindustrial, 3:97-108.

Bianchini, W., Silveira, A.C., Jorge, A.M., Arrigoni, M.B., Martins, C.L., Rodrigues, E., Hadlich, J.C., Andrighetto, C. 2007. Efeito do grupo genético sobre as características de carcaça e maciez da carne fresca e maturada de bovinos superprecoces. Revista Brasileira de Zootecnia, 36:2109-2117.

Bonagurio, S., Pérez, J.R.O., Garcia, I.F.F., Santos, C.L., Lima, A.L. 2004. Composição centesimal da carne de cordeiros Santa Inês puros e de seus mestiços com Texel abatidos com diferentes pesos. Revista Brasileira de Zootecnia, 33:23872393.

Bressan, M.C., Prado, O.V., Pérez, J.R.O., Lemos, A.L.S.C., Bonagurio, S. 2001. Efeito do peso ao abate de cordeiros santa inês e bergamácia sobre as características físico-químicas da carne. Ciência e Tecnologia de Alimentos, 21:293-303.

Cezar, M.F., Sousa, W.H. 2007. Carcaças ovinas e caprinas: obtenção, avaliação e classificação. Editora UFCG, Campina Grande, Brazil. 120p.

Costa, R.G., Batista, A.S.M., Azevedo, P.S., Queiroga, R.C.R.E., Madruga, M.S., Araújo Filho, J.T. 2009. Lipid profile of lamb meat from different genotypes submitted to diets with different 
energy levels. Revista Brasileira de Zootecnia, 38:532-538

Costa, R.G., Pinto, T.F., Medeiros, G.R., Medeiros, A.N., Queiroga, R.C.R.E., Treviño, I.H. 2012. Meat quality of Santa Inês sheep raised in confinement with diet containing cactus pear replacing corn. Revista Brasileira de Zootecnia, 41:432-437.

Elmore, J.S., Cooper, S.L., Enser, M., Mottram, D.S., Sinclair, L.A., Wilkinson, R.G., Wood, J.D. Dietary manipulation of fatty acid composition in lamb meat and its effect on the volatile aroma compounds of grilled lamb. Meat Science, 69:233-242.

Fernandes, A.R.M., Sampaio, A.A.M., Henrique, W., Tullio, R.R., Oliveira, E.A., Silva, T.M. 2009. Composição química e perfil de ácidos graxos da carne de bovinos de diferentes condições sexuais recebendo silagem de milho e concentrado ou cana-de-açúcar e concentrado contendo grãos de girassol. Revista Brasileira de Zootecnia, 38:705-712.

Folch, J., Less, M., Stanley, S.A. 1957. Simple method for the isolation and purification of total lipids from animal tissues. Journal of Biological Chemistry, 226:497-509.

Hartman, L., Lago, R.C.A. 1973. Rapid preparation of fatty acids methyl esters. Laboratory Practice, 22:475-476.

Herdmann, A. Martin, J., Nuernberg, G., Wegner, J., Dannenberger, D., Nuernberg, K. 2010. How do n-3 fatty acid (short-time restricted vs unrestricted) and n-6 fatty acid enriched diets affect the fatty acid profile in different tissues of German Simmental bulls? Meat Science, 86:712719.

Jardim, R.D., Osório, J.C.S., Osório, M.T.M., Mendonça, G., Del Pino, F.A.B., Oliveira, M., Prediée, G. 2007. Composição tecidual e química da paleta e da perna em ovinos da raça Corriedale. Revista Brasileira de Agrociência, 13:231-236.

Lima Júnior, D.M., Monteiro, P.B.S., Rangel, A.H.N., Urbano, S.A., Maciel, M.V. 2011 . Alimentos funcionais de origem animal. Revista Verde de Agroecologia e Desenvolvimento Sustentável, 6:30-40.

Madruga, M.S., Sousa, W.H., Rosales, M.D., Cunha, M.G.G., Ramos, J.L.F. 2005. Qualidade da carne de cordeiros Santa Inês terminados com diferentes dietas. Revista Brasileira de Zootecnia, 34:309-315.

Maia, M.O., Costa, F.S., Susin, I., Rodrigues, G.H., Ferreira, E.M., Pires, A.V., Gentil, R.S., Mendes, C.Q. Efeito do genótipo sobre a composição química e o perfil lipídico da carne de borregas.
Revista Brasileira de Zootecnia, 41:986-992.

Osório, J.C.S., Osório, M.T.M., Sañudo, C. 2009. Características sensoriais da carne ovina. Revista Brasileira de Zootecnia, 38:292-300.

Pinheiro, R.S.B., Silva Sobrinho, A.G., Souza, H.B.A., Yamamoto, S.M. 2009. Qualidade de carnes provenientes de cortes da carcaça de cordeiros e de ovinos adultos. Revista Brasileira de Zootecnia, 38:1790-1796.

Ramos, E.M., Gomide, L.A.M. 2009. Avaliação da qualidade de carnes: fundamentos e metodologias. Editora UFV, Viçosa, Brazil. 599p.

Rioux, V., Legrand, P. 2007. Saturated fatty acids: simple molecular structures with complex cellular functions. Current Opinion in Clinical Nutrition and Metabolic Care, 10:752-775.

Santos Filho, H.B., Véras, R.M.L., Ferreira, M.A., Silva, J.L., Vasconcelos, G.A., Soares, L.F.P., Cardoso, D.B. 2015. Liquid residue of cassava as a replacement for corn in the diets of sheep. Tropical Animal Health and Production, 47:791798.

Santos-Silva, J., Mendes, I.A., Bessa, R.J.B. 2002. The effect of genotype, feeding system and slaughter weight on the quality of light lambs 1 . Growth, carcass composition and meat quality. Livestock Production Science, 76:17-25.

Scollan, N.D., Dewhurst, R.J., Moloney, A.P., Murphy, J.J. 2005. Improving the quality of products from grassland. International Grassland, 23:41-56.

Silva, D.C., Queiroz, A.C. 2002. Análise de alimentos: métodos químicos e biológicos. Editora UFV, Viçosa, Brazil. 235p.

Silva, N.V., Silva, J.H.V., Coelho, M.S., Oliveira, E.R.A., Araújo, J.A., Amâncio, A.L.L. 2008. Características de carcaça e carne ovina: uma abordagem das variáveis metodológicas e fatores de influência. Acta Veterinária Brasilica, 2:103-110.

Sposito, A.C., Caramelli, B., Fonseca, F.A.H., Bertolami, M.C. 2007. IV Diretriz Brasileira Sobre Dislipidemias e Prevenção da Aterosclerose Departamento de Aterosclerose da Sociedade Brasileira de Cardiologia. Arquivos Brasileiros de Cardiologia, 88:1-19.

Urbano, S.A., Ferreira, M.A., Oliveira, J.P.F., Lima Júnior, D.M., Andrade, R.P.X. 2014. Fontes de gordura sobre a modulação do perfil lipídico da carne de pequenos ruminantes. Archivos de Zootecnia, 63:147-171.

Vieira, M.M.M., Cunha, M.G.G., Garrutti, D.S., Duarte, T.F., Félex, S.S.S., Pereira Filho, J.M., 
Silva et al. (2018) / Physicochemical composition...

Madruga, M.S. 2010. Propriedades físicas e sensoriais da carne de cordeiros Santa Inês terminados em dietas com diferentes níveis de caroço de algodão integral (Gossypium hirsutum). Ciência e Tecnologia de Alimentos, 30:372-377.

Wheeler, T.T., Cundiff, L.V., Koch, R.M. 1995. Effects of marbling degree on palatability and caloric content of beef. Beef Research Program Progress Report, 71:133-134.

Wood, J.D., Enser, M., Fisher, A.V., Nute, G.R., Sheard, P.R., Richardson, R.I., Hughes, S.I., Whittington, F.M. 2008. Fat deposition, fatty acid composition and meat quality: A review. Meat Science, 78:343-358. 